\title{
Relato de docência ou como aprendi praticando
}

\author{
Demétrio Alves Paz* \\ "As a teacher, you should care about the human heart, not just about education."
}

$14^{\text {th }}$ Dalai Lama

O que relato a seguir é sobre a minha experiência com o ensino de português, no colégio de Aplicação, no qual trabalhei durante dois anos (2001-2003) como professor substituto de Língua Portuguesa e Literatura Brasileira. Gostaria de deixar aqui o meu agradecimento pelo apoio recebido por todos os professores da escola que trabalharam comigo. Seus conselhos e suas práticas serviram-me de modelo e ajudaram, acredito eu, a transformar-me num profissional mais capacitado. Como não poderia deixar de ser, o contato diário fez com que eu convivesse mais com os meus colegas de Divisão. Agradeço a eles pelo carinho, dedicação, paciência, prontidão e por tudo o que me ensinaram com a sua vasta experiência no ensino. Meu muito obrigado as professoras Gláucia de Souza, Juçara Benvenuti, Margarete Studbrack, Carmen Medina, Fátima Berro e ao professor Tadeu Rossato Bisognin pelas várias discussões e lições de língua e literatura. Agradeço também aos, naquela época, diretor Jorge Barreto e vice-diretor Adalberto Breier pela confiança que tiveram no meu trabalho.

Nesses dois anos, lecionei português na $8^{\mathrm{a}}$ série $(82 \mathrm{em}$ 2001, 81 em 2002). Com o que aprendi, julgo necessário discutir alguns pontos para um ensino de língua materna mais condizente com a realidade de nossos alunos. Ensino esse que, na maioria das vezes, tem sido repressor e não tem acrescentado nada à

* Doutor em Literatura. Professor Adjunto 1 da Universidade Federal da Fronteira Sul (UFFS) Campus Cerro Largo. E-mail: demetriopaz@gmail.com 
construção de conhecimento dos nossos alunos. A minha prática em sala de aula partiu de uma sugestão de Celso Pedro Luft, em Lingua e Liberdade, que propõe: "Uma prática sem medo, num ensino sem opressão: no mais íntimo terreno da vida humana, que é o da linguagem, onde estruturamos o mundo em nosso interior e nos ligamos a ele, isso se faz mais que necessário, é vital". (LUFT, 1995, p. 12).

As aulas de português deveriam ser as melhores aulas em nossas escolas, afinal essa é a nossa língua materna, a que usamos no dia a dia. Entretanto, não é isso o que acontece. Para muitos alunos ela é, na maioria das vezes, a mais enfadonha e difícil. Se alguém não acreditar, basta perguntar para qualquer estudante qual é a disciplina mais difícil. Por que isso? Muitos professores têm confundido aula de português com ensino de gramática; leitura, com textos do livro didático, e produção textual, com redações sobre os temas mais chatos possíveis.

O que proponho é que escutemos mais os nossos alunos e usemos mais suas ideias em sala de aula. De certa forma, no mundo atual, a escola é o único local em que esses jovens podem ser ouvidos, e se nós não os escutarmos, ninguém o fará. A escola, felizmente ou não, tem sido o local de educação desses jovens, visto que a família moderna passou-nos também essa responsabilidade. No Colégio de Aplicação, temos a oportunidade de trabalhar com um número menor de turmas e um contato maior com os alunos. Desse modo, para a maioria dos alunos e dos professores, o colégio é a segunda casa. $\mathrm{O}$ trabalho que se faz também é diferenciado, pois os alunos têm a oportunidade de sanar suas dúvidas e dificuldades no laboratório de ensino, oferecido em turno inverso, uma vez por semana.

A seguir mostrarei o que fiz e como fiz para tornar, penso eu, minhas aulas interessantes e estimulantes. Para tanto, usei muitas vezes metodologia de ensino de segunda língua, por ter experiência com o ensino de Língua Inglesa. 


\section{Usar o conhecimento deles}

Nas minhas aulas, eu conduzia o trabalho pedindo aos alunos exemplos, elementos para o andamento da aula, isto é, fazia com que eles participassem ativamente do processo de construção do conhecimento. Afinal, a minha preocupação era mais com a produção, a compreensão e qualidade do que com a quantidade de conteúdo a ser aprendido. Isso é conhecido como, em metodologia de ensino de segunda língua, ensino centrado no aluno, no qual ele é a principal preocupação. Nem sempre eles tinham a resposta ou a solução, mas buscavam compreender o que estava ocorrendo.

\section{Determinar o tempo das atividades}

Delimitar o tempo para cada atividade é bom, pois desenvolve a criatividade e o raciocínio rápido em cada um, assim como estimula a organização. Ao ter de realizar em X minutos uma tarefa, não podendo desperdiçar seu tempo e atenção, o aluno sente-se desafiado e busca soluções criativas e eficazes para a sua melhor realização.

Nessa situação, o aluno aprende a valorizar a organização de ideias e a explorar todos os seus recursos e habilidades, resultando num crescimento pessoal e intelectual. Sabemos que cada um tem o seu tempo, mas, enquanto educadores, devemos mostrar-lhes que podem aprender a acelerar o seu ritmo.

\section{Sirva como exemplo}

Esse, muitas vezes, é o mais difícil. Se você exige postura, tenha postura; se exige educação, seja educado; se exige respeito, respeite. Como nos ensina o Dalai Lama (apud Bender 1996/1997, p. 24): 
[...] seus alunos devem enxergar pelo seu comportamento que você está realmente comprometido e preocupado com o bem-estar e o futuro deles. Se eles enxergarem, seus alunos confiarão e respeitarão você, e os valores que o seu comportamento reflete deixará uma impressão indelével em suas mentes. A mente compassiva é como um elixir; é capaz de transformar situações difíceis em proveitosas.

Combine com seus alunos normas de comportamento, fazendo com que eles deem sugestões e formulem as regras. Você verá a diferença. Depois desse momento, na medida em que um falhar, todos cobrarão dele a conduta certa.

\section{Escrever para alguém}

Minhas aulas foram baseadas na pedagogia de projetos proposta por Ana Maria Kaufman e Maria Elena Rodriguez (1996, p. 5) que propõem o "[...] planejamento de projetos didáticos que levem em consideração a produção de textos, incluídos em uma situação comunicativa precisa, com destinatários reais".

Por exemplo, fiz um projeto de escrita de poesia em que eles sabiam que teriam leitores fora do círculo professor-aluno, pois tínhamos combinado que no final espalharíamos vários cartazes pela sala e pelos corredores do colégio.

Sabendo que outros poderiam ler os seus trabalhos, o comprometimento, a preocupação e a dedicação na produção foram bons, diria até excelentes, portanto é necessário que se desenvolvam mais projetos como esse, qual seja, divulgar a produção individual do aluno, fazendo com que ele sinta orgulho e prazer ao ver seu trabalho exposto.

\section{Motivar o aluno em sua produção}

Aqui está o grande problema do ensino, em geral, hoje em dia. Não há motivação, o professor não incentiva o aluno, e este se sente um nada. As provas/trabalhos são entregues com 
uma nota, sem nenhum comentário, não acrescentando nada ao conhecimento adquirido para aquele fim. Tanto faz se aquela prova ou trabalho forem guardados ou postos fora, não farão a mínima diferença para ninguém.

Como aprendi no Aplicação, nos trabalhos dos meus alunos escrevia sempre comentários, dizendo o que poderia ser melhorado. Quanto aos erros de ortografia, sugeria que eles procurassem as palavras no dicionário, ressaltando, sempre que possível, a importância dele na aquisição de conhecimento, pois ali estão registradas várias palavras e seus significados. Além disso, para cada palavra errada deveria ser escrita uma frase, usando-a corretamente. Também os incentivava a pesquisarem sobre autores, obras e outros assuntos de seu interesse, aconselhando-os a irem à biblioteca para pesquisar.

É por tudo isso e muitas outras experiências que tive como professor e aluno que recomendo uma maior preocupação com o aluno como ser humano e um maior envolvimento e comprometimento com o ensinar. Afinal, é ensinando que nós, professores, aprendemos e assim podemos corrigir nossas falhas, o que nos permite um crescimento maior profissional e pessoalmente.

Ao trabalhar com os estudantes, a minha preocupação era fazer uma aula de português como Luft (1995, p. 19). Aconselha, isto é, com “[...] leitura, comentário, análise e interpretação de bons textos, e tentativa constante de produzir, pessoalmente, textos bons $[\ldots]$ ".

\section{Referências}

BENDER, Henry. The dalai Lama on Kids Today. In: Educational Leadership, v. 54, n. 4. Dec. 1996/Jan., 1997.

KAUFMAN, Ana Maria; RODRÍGUEZ, Maria Elena. Escola, leitura e produção de textos. Porto Alegre: Artes Médicas, 1996.

LUFT, Celso Pedro. Língua e liberdade. São Paulo: Ática, 1995. 